\title{
State Actions for Wrongful Discharge: Overcoming Barriers Posed by Federal Labor Law Preemption
}

The "employment at will" doctrine provides that, absent contrary statutory or contractual provisions, an employer may discharge an employee for good cause, bad cause, or no cause whatsoever. ${ }^{1}$ Today, many employees are protected from potentially harsh and unjust effects of this doctrine by collective bargaining agreements, civil service legislation and antidiscrimination statutes. Most of today's work force, however, is still employed under contracts terminable at will, and many discharged employees find statutory protections inapplicable to their situations.

Courts have responded to the harsli effects of the rule by limiting the at will doctrine througl application of doctrines from other areas of the law. Recent decisions in California liave articulated three such limitations: a public policy exception to the doctrine, ${ }^{2}$ a limitation based on implied-in-fact contract rights, ${ }^{3}$ and a limitation based on the implied-in-law covenant of good faitl and fair dealing. ${ }^{4}$

These exceptions to the at will doctrine enable einployees to secure redress for wrongful discharges, and, as such, offer them long overdue protection. The recognition of common law causes of action for wrongful discharge, lowever, raises questions regarding the interplay of such actions witl protections available under state and federal statutes. Although common law actions can fill statutory gaps and provide supplemental relief, courts may apply several doctrines, including fed-

1. Union Labor Hosp. Ass'n v. Vance Redwood Lumber Co., 158 Cal. 551, 554, 112 P. 886, 888 (1910); Payne v. Western \& A.R.R., 81 Tenn. 507, 519-20 (1884). California codified the at will doctrine in CAL. LAB. CoDE $\S 2922$ (West Supp. 1983), quoted at infra note 21.

This doctrine has long been criticized by commentators as harsli and unjust to the employee. E.g., Blades, Employment at Will vs. Individual Freedom: On Limiting the Abusive Exercise of Employer Power, 67 Colum. L. Rev. 1404 (1967); Peck, Unjust Discharges From Employment: A Necessary Change in the Law, 40 Oноо ST. L.J. 1 (1979); Summers, Individual Protection Against Unjust Dismissal: Time for a Statute, 62 VA. L. REv. 481 (1976).

2. Tameny v. Atlantic Richfield Co., 27 Cal. 3d 167, 172, 610 P.2d 1330, 1332-33, 164 Cal. Rptr. 839, 841-42 (1980). (1981).

3. Pugh v. See's Candies, Inc., 116 Cal. App. 3d 311, 326-30, 171 Cal. Rptr. 917, 925-27

4. Cleary v. American Airlines, 111 Cal. App. 3d 443, 455, 168 Cal. Rptr. 722, 729 (1980). 
eral preemption, exhaustion of administrative remedies, pendent jurisdiction and res judicata, to preclude common law relief.

This Comment focuses on the doctrine of federal preemption and the potential exemption of state wrongful discharge actions by the $\mathrm{Na}$ tional Labor Relations Act (NLRA). ${ }^{5}$ Part I of this Comment briefly traces the development of the at will rule and the exceptions recognized by Califorina courts. Part II reviews the scope of the evolving labor law preemption doctrine under the NLRA. Part III analyzes some of the issues state courts need to consider in applying the Supreme Court's preemption analysis to state wrongful discharge actions.

\section{I}

\section{The At Will Doctrine and California's Exceptions}

\section{A. The Employment At Will Doctrine}

Numerous scholars have elaborated on the origin of the employment at will doctrine and its justifications. ${ }^{6}$ Briefly stated, the nineteenth century rule in England provided that a term of employment was presumed to be for one year unless another term was specified. ${ }^{7}$ American courts in the nineteenth century followed the presumption that a ternn was for a year unless another period was specified or could be implied from surrounding circumstances. ${ }^{8}$ H.G. Wood, in his 1877 treatise on the master and servant relationship, however, reversed the traditional presumption and formulated the employment at will doctrine as follows: "With us the rule is inflexible, that a general or indefiinte hiring is prima facie a hiring at will, and if the servant seeks to make it out a yearly hiring, the burden is upon him to establish it by proof."

The at will doctrine, or Wood's rule, as it has also been called, enjoyed rapid acceptance among American jurisdictions, despite a lack of authority cited im support of its initial statement. ${ }^{10}$ Various ratio-

5. 29 U.S.C. $\S \S 151-169$ (1973).

6. See, e.g., P. Selznick, Law, Society, ANd Industrial Justice 122-37 (1969); Summers, supra note 1, at 484-91; Note, Job Security for the At Will Employee: Contractual Right of Discharge for Cause, 57 CHI.-KENT L. REv. 697, 699-706 (1981) [heremafter cited as Note, Job Security for the At Will Employee]; Note, Implied Contract Rights to Job Security, 26 STAN. L. Rev. 335, 340-47 (1974) [hereinafter cited as Note, Implied Contract Rights].

7. $1 \mathrm{~W}$. Blackstone, Commentaries $* 425$.

8. See, e.g., Smith v. Theobald, 86 Ky. 141, 5 S.W. 394 (1887); Adams v. Fitzpatrick, 125 N.Y. 124, 26 N.E. 143 (1891); Davis v. Gorton, 16 N.Y. 255 (1857); Bascom v. Shillito, 37 Ohio St. 431 (1882). But see Kirk v. Hartman \& Co., 63 Pa. 97 (1869) (stating that employınent is terminable at will).

9. H.G. Wood, A Treatise on the Law of Master and Servant § 134, at 272 (1877).

10. Wood cited four American cases as authority for his rule. For a discussion of these cases and their failure to support the rule, see Note, Implied Contract Rights, supra note 6, at 341-42 nn.53-54; Note, Job Security for the At Will Employee, supra note 6, at 700 n.20. 
nales have been suggested for its immediate and ongoing acceptance: the prevailing freedoin of contract and laissez faire econounic principles at the turn of the century, ${ }^{11}$ a capitalisin-engendered power struggle between middle level managers and business owners, ${ }^{12}$ and the inutuality of obligation requirement in contract law. ${ }^{13}$

In California, as in other states, contract principles such as mutuality of obhgation have contributed to the perpetuation of the at will rule even after the decline of absolute freedoin of contract principles. The inutuality doctrine supports the reasoning that if an einployee may quit her einployment at will, the einployer, too, inust have the right to terminate the relationship at will. ${ }^{14}$ California courts have thus held that a limitation on an employer's power of discharge inust be supported by consideration independent of the einployee's promise to perfornt services. ${ }^{15}$

The mutuality of obligation doctrine, however, has been severely criticized. Numerous authorities have suggested that courts should dispense with the idea that both parties inust be bound or neither is bound. ${ }^{16}$ Accorling to one authority, "the supposed requirement of inutuality of obligation is inerely one of inutuality of consideration: Each contractimg party inust supply consideration to the other." 17 But

11. P. SELZNICK, supra note 6, at 130-37 (describing the emergence of the contractual theory of employment from the old master-servant doctrine-and the concomitant shift of emphasis from obligation to freedom of choice-when freedom of contract became the ideal in both politics and trade).

In the early 20 th century, the employer's absolute right of discharge was found to be a constitutionally guaranteed property right. See Adair v. United States, 208 U.S. 161, 174-76 (1908); Coppage v. Kansas, 236 U.S. 1, 10-11 (1915). For a discussion of these cases and their dccline after the Supreme Court upheld the National Labor Relations Act in NLRB v. Jones \& Laughlin Steel Corp., 301 U.S. 1 (1937), see Blades, supra note 1, at 1416-19; Comment, The Employment At Will Rule, 31 ALA. L. Rev. 421, 426-28 (1980) [hereinafter cited as Comment, Employment At Will Rule]; Cominent, Protecting At Will Employees Against Wrongful Discharge: The Duty to Terminate Only in Good Faith, 93 HARv. L. REv. 1816, 1826 (1980) [hereinafter cited as Counment, Protecting At Will Employees].

12. Feinman, The Development of the Employment At Will Rule, 20 AM. J. LEGAL Hist. 118, 131 (1976).

13. See, e.g., Lord v. Goldberg, 81 Cal. 596, 601-02, 22 P. 1126, 1128 (1889); Mallard v. Boring, 182 Cal. App. 2d 390, 394, 6 Cal. Rptr. 171, 174 (1960); Blades, supra note 1, at 1419; Comment, Recognizing the Employee's Interests in Continued Employment-The California Cause of Action for Unjust Dismissal, 12 PAC. L.J. 69, 74-75 (1980).

14. Blades, supra note 1, at 1419; see, e.g., Mallard v. Boring, 182 Cal. App. 2d 390, 394, 6 Cal. Rptr. 171, 174 (1960).

15. See, e.g., Ruinello v. Murray, 36 Cal. 2d 687, 689-90, 227 P.2d 251, 253 (1951).

16. See J. Calamari \& J. Perillo, The Law of Contracts § 4-14 (2d ed. 1977); 1 A A. Corbin, Corbin on Contracts $§ 152$ (1963); Restatement (Second) of Contracts $§ 79$ (1981). 20.

17. J. Calamari \& J. Perlllo, supra note $16, \S 4-14$. See also Blades, supra note 1 , at 1419. 
one consideration may support many promises, ${ }^{18}$ such that an employee's promise to render services might support an employer's promise to pay wages as well as a promise not to dismiss the employee without good cause. ${ }^{19}$ In California, recent court decisions have reduced the requirement of independent consideration from a rule of substance to a rule of construction, thus undercutting the mutuality rationale. Accordingly, a contract for permanent employment cannot be terminated at will if it contains an express or implied condition to the contrary. ${ }^{20}$

Despite the apparent demise of the mutuality of obligation doctrine and the requirement of independent consideration, many states, includimg California, ${ }^{21}$ have codified the at will rule, and courts have continued to apply it. Recent decisions have relied on the at will rule to uphold discharges of employees for refusing to falsify medical records, ${ }^{22}$ filing workmen's compensation claims, ${ }^{23}$ warning superiors that one of the employer's products was not adequately tested and constituted a serious danger to the consumer, ${ }^{24}$ reporting a superior for soliciting and receiving kickbacks, ${ }^{25}$ sympathizing with employees' efforts to unionize a plant, ${ }^{26}$ and proclaiming availability for jury duty. ${ }^{27}$

The United States is among the few industrial nations which do not provide general protection against wrongful discharge. ${ }^{28}$ Employees belonging to unions, however, are usually protected by a clause in the collective-bargaining agreement requiring just cause for termina-

18. J. CALAmar1 \& J. Perillo, supra note 16, §4-22; 1A A. CorbiN, supra note 16, § 125; RestateMENT (SECOND) OF CONTRACTS $\$ 80$ (1981).

19. Pugh v. See's Candies, Inc., 116 Cal. App. 3d at 325-26, 171 Cal. Rptr. at 925.

20. See Drzewiecki v. H \& R Block, lnc., 24 Cal. App. 3d 695, 703-04, 101 Cal. Rptr. 169, 174 (1972); accord Rabago-Alvarez v. Dart Indus., 55 Cal. App. 3d 91, 96, 127 Cal. Rptr. 222, 225 (1976).

21. California has codified the at will doctrine as follows: "An employment, having no specified term, may be terminated at the will of either party on notice to the other. Employment for a specified term means an employment for a period greater than one month." CAL. LAB. CODE $\S 2922$ (West Supp. 1983).

22. Hinrichs v. Tranquilaire Hosp., 352 So. 2d 1130 (Ala. 1977).

23. Loucks v. Star City Glass Co., 551 F.2d 745 (7th Cir. 1977); Martin v. Tapley, 360 So. 2d 708 (Ala. 1978); Segal v. Arrow Indus. Corp., 364 So. 2d 89 (Fla. Dist. Ct. App. 1978).

24. Geary v. United States Steel Corp., 456 Pa. 171, 319 A.2d 174 (1974).

25. Martin v. Platt, — Ind. App. -, 386 N.E.2d 1026 (1979).

26. Simmons v. Westinghouse Elec. Corp., 311 So. $2 d 28$ (La. Ct. App. 1975).

27. Mallard v. Boring, 182 Cal. App. 2d 390, 6 Cal. Rptr. 171 (1960).

28. For a discussion of the statutory protections available in several European countries, see Summers, supra note 1, at 509-19. The French principle of "abuse of right," for example, prohibits terminations where the employer "acted with malicious intent, culpable negligence, or capriciousness." Id. at 510 . Germany prohibits "socially unwarranted dismissals," i.e., the discharge must be based on the employee's conduct regarding the job and "must be necessary to the effective operation," Id. at 511-13. Great Britain prohibits unfair dismissal, id. at 513-15, and Sweden requires "objective cause" for termination, id. at 517-19. 
tion of employees. ${ }^{29}$ Moreover, a number of state and federal statutes provide protection against certain types of discharges. Federal law protects employees from discharge because of race, color, religion, sex, national origin, ${ }^{30}$ age, ${ }^{31}$ or wage garnishment. ${ }^{32}$ Returning veterans ${ }^{33}$ and civil servants ${ }^{34}$ enjoy similar federal protection. California statutes forbid discharges on the basis of race, religion, sex,,$^{35}$ or age, ${ }^{36}$ and discharges in retaliation for engaging in union activity, ${ }^{37}$ for serving on a jury, ${ }^{38}$ and for engaging im political activity. ${ }^{39}$ Despite such protections, it has been estimated that between sixty and sixty-five percent of the nonagricultural work force is employed under contracts that are terminable at will. ${ }^{40}$

\section{B. Limitations to the At Will Doctrine}

Although various scholars have urged the enactment of legislation providing a limit on the at will doctrine that would take imto account the conflicting interests of employees and employers, ${ }^{41}$ such legislation has not been forthcoming. Thus, much of the responsibility for himiting the at will doctrine has fallen upon the courts. California courts recognize three such limitations: a public policy exception to the rule; implied-in-fact contract rights to continued einployment; and an implied-im-law covenant of good faith and fair dealing.

\section{The Public Policy Exception}

Several jurisdictions have recognized an exception to the at will

29. Approximately $22 \%$ of American employees are unionized. Comment, Protecting At Will Employees, supra note 11, at 1816 n.2. A survey of the major types of provisions in collectivebargaining agreements conducted by the Bureau of National Affairs found that $99 \%$ of the contracts studied contained grievance procedures and $96 \%$ provided for arbitration. 2 Collective BaRGaINING, Negotiations \& CoNTRACTs (BNA) 40:1, $51: 1$ (1979). Grounds for discharge provisions were found in $90 \%$ of the contracts; $80 \%$ included provisions that employees may be discharged only for "cause" or "just cause." $I d$. at $51: 5$. In the absence of such a provision, arbitrators often read one into the contract. Summers, supra note 1, at 499-500.

30. Civil Rights Act of $1964 \$ 8701-716$ (tit. VII), 42 U.S.C. $\$ 2000 \mathrm{e}-2$ (a)(1) (1976). 1981).

31. Age Discrimination in Employment Act of 1967, 29 U.S.C. $\$ 623$ (a)(1) (1976 \& Supp. V

32. Consumer Credit Protection Act of 1969 § 304(a), 15 U.S.C. $§ 1674(a)$ (1976).

33. Vietnam Era Veteran's Readjustment Assistance Act of 1974, § 404(a), 38 U.S.C. § 2021(a), (b)(1), (b)(3) (1976).

34. Civil Service Reform Act of 1969, 5 U.S.C. \& 7513 (Supp. IV 1980).

35. CAL. Gov't CODE $\$ 12940$ (a) (West Supp. 1983).

36. Id. $§ 12941$.

37. CaL. LAB. Code $\$ \$ 922-923$ (West 1971).

38. Id. $\S 230$ (West Supp. 1982).

39. Id. \$ 1102 (West 1971).

40. Peck, supra note 1 , at 9.

41. See id. at 48-49; Summers, supra note 1, at 519-32. 
doctrine when a discharge "contravenes the dictates of public policy."42 Courts have found public policy violations where an employee was terminated for serving on a jury contrary to her employer's wishes, ${ }^{43}$ for atteinpting to persuade his employer to comply with consumer protection laws, ${ }^{44}$ for filing a workmen's compensation claim, ${ }^{45}$ for refusing to take a polygraph test, ${ }^{46}$ and for refusing to alter pollution control reports required by the state. ${ }^{47}$ Similarly, California courts have held that einployers may not discharge employees for refusing to commit perjury, ${ }^{48}$ for applying for umion membership, ${ }^{49}$ or for seekmg assistance in securing a minimum wage. ${ }^{50}$ The courts have recognized that a discharge in contravention of public policy is actionable in tort, potentially entitling a plaintiff to compensatory and punitive damages. ${ }^{51}$

In Tameny v. Atlantic Richfield Co. ${ }^{52}$ the California Supreme Court held that an employer may not discharge an employee for refusing to participate in a price-fixing scheme. Expressly recognizing the public policy exception to the at will doctrine, the majority stated:

[A]n employer's obligation to refrain from discharging an employee who refuses to commit a criminal act . . . reflects a duty imposed by law upon all einployers in order to implement the fundamental public policies embodied in the state's penal statutes. As such, a wrongful discharge suit exhibits the classic elements of a tort cause of action. ${ }^{53}$

The court in Tameny did not indicate whether the public policy allegedly violated by an einployer inust be embodied by a statute, criminal or otherwise. Although the court rejected the einployer's attempt to distinguish prior cases on the ground that in those cases statutes explicitly prohibited the discharges, ${ }^{54}$ the court did not directly address whether the public policy exception would apply where the employee

42. Tameny v. Atlantic Richfield Co., 27 Cal. 3d 167, 177, 610 P.2d 1330, 1336, 164 Cal. Rptr. 839, 845 (1980).

43. Nees v. Hocks, 272 Or. 210, 536 P.2d 512 (1975).

44. Harless v. First Nat'1 Bank, 246 S.E.2d 270, 275-76 (W. Va. 1978).

45. Frampton v. Central Ind. Gas Co., 260 Ind. 249, 253, 297 N.E.2d 425, 427-28 (1973);

Sventko v. Kroger Co., 69 Mich. App. 644, 649, 245 N.W.2d 151, 153-54 (1976).

46. Perks v. Firestone Tire \& Rubber Co., 611 F.2d 1363, 1366 (3d Cir. 1979).

47. Trombetta v. Detroit, T. \& I.R.R., 81 Mich. App. 489, 496, 265 N.W.2d 385, 388 (1978).

48. Petermann v. International Bhd. of Teamsters, 174 Cal. App. 2d 184, 188-89, 344 P.2d 25, 27-28 (1959).

49. Glenn v. Clearman's Golden Cock Inn, 192 Cal. App. 2d 793, 796-97, 13 Cal. Rptr. 769, 772 (1961); cf. Wetherton v. Growers Farm Labor Ass'n, 275 Cal. App. 2d 168, 174-75, 79 Cal. Rptr. 543, 547-48 (1969).

50. Montalvo v. Zamora, 7 Cal. App. 3d 69, 75, 86 Cal. Rptr. 401, 404 (1970).

51. See, e.g., cases cited supra notes 42-46; Sheets v. Teddy's Frostcd Foods, Inc., 179 Conn. 471, 474, 427 A.2d 385, 388-89 (1980); Kelsay v. Motorola, Inc., 74 Ill. 2d 172, 181-82, 384 N.E.2d 353, 359-60 (1979); Reuther v. Fowler \& Williams, Inc., 255 Pa. Super. 28, 386 A.2d 119 (1978).

52. 27 Cal. 3d 167, 178, 610 P.2d 1330, 1337, 164 Cal. Rptr. 839, 846 (1980).

53. Id. at 176,610 P.2d at $1335,164 \mathrm{Cal}$. Rptr. at 844 .

54. Id. at 177,610 P.2d at 1336, $164 \mathrm{Cal}$. Rptr. at 845 . But see id. at 179,610 P.2d at 1337 , 
does not rely on a statute. It did, however, discuss Nees v. Hocks, ${ }^{55}$ a case in which the Oregon Supreme Court found a public policy violation in the absence of a statute, as "illustrative of a rapidly growing number of cases ... [recognizing] a common law tort action for wrongful discharge in cases im which the termination contravenes pubhic policy."56

\section{Implied-in-Fact Contract Rights}

In addition to providing tort remedies for discharges made in violation of public policy, a few courts recognize a limitation to the at will rule based on contract law. Here, the courts read a promise to refrain from discharging an employee arbitrarily into the einployer-employee contractual relationship. ${ }^{57}$

In Pugh v. See's Candies, Inc., ,8 a California appellate court found that an employee's longevity of employment, the commendations, promotions, and assurances he received from his employer, togetler with the employer's acknowledged pohicies, could give rise to an implied promise that the employee would be discharged only for "good cause."59 According to the court, "good cause" connotes " "a fair and honest.cause or reason, regulated by good faith on the part of the party exercising the power." "60 It is a standard different from that applicable in determining the propriety of an employee's ternimation under a contract for a specified ternı and it is different from the "just cause" referred to in collective-bargaining agreements. ${ }^{61}$

164 Cal. Rptr. at 846 (Manuel, J., concurring) (finding the cause of action at bar to flow froin a statutory source).

55. 272 Or. 210,536 P.2d 512 (1975).

56. $27 \mathrm{Cal}$. 3d at 178, 610 P.2d at 1336, 164 Cal. Rptr. at 845 . In addition, the court did not indicate whether a statute providing for administrative relief might also constitute the basis for a public policy exception to the at will rule. In other jurisdictions, courts disagree on that issue. Compare, e.g., McGinley v. Burroughs Corp., 407 F. Supp. 903, 910 (E.D. Pa. 1975) (allowing a wrongful discharge action), with Bonham v. Dresser Indus., 569 F.2d 187, 192 (3d Cir.), cert. denied, 439 U.S. 821 (1978), and Wehr v. Burroughs Corp., 438 F. Supp. 1052, 1055-56 (E.D. Pa. 1977) (not allowing such an action). Even whcre such an administrative reinedy is not exclusive, courts may require that plaintiffs exhaust that remedy before seeking comunon law relief under the public policy exception. Pugh v. See's Candies, Inc., $116 \mathrm{Cal}$. App. 3d 311, 323 n.13, $171 \mathrm{Cal}$. Rptr. 917, 923 n.13 (1981).

57. Pugh v. See's Candies, Inc., 116 Cal. App. 3d 311, 329, 171 Cal. Rptr. 917, 927 (1981). See generally Note, Implied Contract Rights, supra note 6.

58. 116 Cal. App. 3d 311, 171 Cal. Rptr. 917 (1981).

59. Id. at 329,171 Cal. Rptr. at 927.

60. Id. at 330, 171 Cal. Rptr. at 928 (quoting R.J. Cardinal Co. v. Ritchie, 218 Cal. App. 2d 124, 145, 32 Cal. Rptr. 545, 558 (1963)). The court recognized that the "legitimate exercise of inanagerial discretion" was not to be interfered with, and that some circuinstances, such as employment in a confidential position, would necessitate allowing the employer more latitude in employment decisions. Id.

61. Id. at 330 n.26, 171 Cal. Rptr. at 928 n.26. 
A more concrete interpretation of good cause was provided by the Michigan Supreme Court in Toussaint v. Blue Cross \& Blue Shield ${ }^{62}$ There, the court indicated that "[w]here the employee has secured a promise not to be discharged except for cause, he has contracted for more than the employer's promise to act in good faith or not to be unreasonable." ${ }^{.3}$ According to the court, the trier of fact should consider whether the asserted reason for discharge is one that could justify the termination of the employment relationship, and whether it demonstrates that the employee was no longer doing the job. ${ }^{64}$ The Toussaint court's construction of good cause, then, provides more protection to the employee than a more subjective good faith standard. The court mdicated that a good faith standard permits discharge so long as the employer's dissatisfaction with the employee's performance is reasonable. ${ }^{65}$ In contrast, a good cause determination justifies discharge only where the einployee has violated objective standards of conduct either established by the employer or, presumably, prevalent within the industry. ${ }^{66}$

The court in Pugh did not address the question of damages. Presumably, plaintiffs in imphied-in-fact contract cases are limited to damages for breach of contract, since in most states, imcluding California, ${ }^{67}$ punitive damages are not recoverable in contract actions. Plaintiffs asserting miplied-in-fact contract rights will thus be afforded less rehief than if they asserted rights based on a covenant of good faith and fair dealing or a public policy.

\section{Implied-in-Law Covenant of Good Faith and Fair Dealing}

The implied covenant of good faith and fair dealing imposes a duty on contracting parties that neither will do anything that will injure the right of the other to receive the benefits of the agreement. ${ }^{68}$ Courts first applied the covenant in the imsurance context. There, the special relationship between the insured and the insurer, the quasi-public nature of the insurer's obligations, and the adhesive quality of imsurance contracts provide courts with justification for awarding punitive dam-

62. 408 Mich. 579,292 N.W.2d 880 (1980).

63. Id. at 623,292 N.W.2d at 896 .

64. Id.

65. Id.

66. Id. at 623-24, 292 N.W.2d at 897. See generally Note, Job Security for the At Will Employee, supra note 6, at 711-15. But see Comment, Protecting At Will Employees, supra note 11, at (good faith standard might be extended to an implied contract obligation to discharge only for just cause); Note, Implied Contract Rights, supra note 6, at 368 (dismissal for cause standard is equivalent to implying a covenant of good faith and fair dealing in the employment contract).

67. CAL. CIV. CoDE $\S 3294$ (West Supp. 1982).

68. Connunale v. Traders \& Gen. Ins. Co., 50 Cal. $2 d$ 654, 658, 328 P.2d 198, 200 (1958) (en banc). 
ages for breach of the covenant. ${ }^{69}$

A number of state courts have found employers who discharge employees in bad faith liable for breach of contract. ${ }^{70}$ In Tameny, the California Supreme Court found it unnecessary to determine whether a tort remedy would be available under the theory that the employer breached the covenant of good faith and fair dealing inherent in every contract. ${ }^{71}$ The California Court of Appeal, in Cleary v. American Airlines, Inc. ${ }^{72}$ later relied in part on the covenant of good faith and fair dealing to find that "the longevity of the employee's service [here, eighteen years], together with the expressed policy of the einployer [regarding employee grievances and discharges], operate as a form of estoppel, precluding any discharge of such an employee by the employer without good cause."73

The Cleary court reasoned that termination of employment without legal cause after eighteen years offends the covenant of good faith and fair dealing. ${ }^{74}$ The implications of this finding, however, are unclear. First, as the court also based its loolding on the existence of the employer's expressed policy, it is not clear whether breach of the covenant alone is sufficient to state a cause of action. ${ }^{75}$ Second, the court did not indicate how far its holding would extend. Although it found that this employer could not discharge the plaintiff without good cause, the court did not specify whether the covenant of good faith and fair dealing requires that good cause be shown for terminations in all cases.

The factors considered by the Cleary court are similar to those later recognized by the Pugh court as giving rise to an implied-im-fact contract right to termination only for just cause. ${ }^{76}$ Characterizing the discharge as a breach of the covenant of good faitl and fair dealing, however, enables a plaimtiff to recover tort as well as contract damages. ${ }^{77}$ Courts will need to determine the scope of the covenant, in hight of the damages available, and to decide whether, in the absence of factors such as those delineated in Cleary, "good faitll" requires termi-

69. Egan v. Mutual of Omaha Ins. Co., 24 Cal. 3d 809, 820, 598 P.2d 452, 457-58, 157 Cal. Rptr. 482, $487-88$ (1979), cert. denied, 445 U.S. 912 (1980).

70. E.g. Fortune v. National Cash Register Co., 373 Mass. 96, 104, 364 N.E.2d 1251, 1257. 58 (1977) (plaintiff salesman terminated just as he was to complete a sale so that the employer could avoid paying certain bonuses); Monge v. Beebe Rubber Co., 114 N.H. 130, 133, 316 A.2d 549,551 (1974) (plaintiff discharged for refusing to date her foreman).

71. 27 Cal. 3d at 179 n.12, 610 P.2d at 1337 n.12, 164 Cal. Rptr. at 846 n.12.

72. 111 Cal. App. 3d 443, 168 Cal. Rptr. 722 (1980).

73. Id. at 455-56, $168 \mathrm{Cal}$. Rptr. at 729.

74. Id. at 455, 168 Cal. Rptr. at 729.

75. But see Cancellier v. Federated Dep't Stores, 672 F.2d 1312, 1318 (9th Cir.) (citing Pugh and Cleary to support the proposition that California courts have recognized the duty created by the implicd covenant), cert. denied, 103 S. Ct. 131 (1982).

76. See supra note 59 and accompanying text.

77. Cleary, 111 Cal. App. 3d at 456, 168 Cal. Rptr. at 729. 
nation only for just cause or permits reasonable, albeit subjective, discharges.

Thus, California courts have applied various theories on which to mitigate the liarsh effects of the employment at will doctrine. Where the facts in a particular case do not suggest a public policy violation or give rise to implied-in-fact contract riglits, the covenant of good faith and fair dealing might provide courts with a flexible standard to apply on a case-by-case basis to balance the employer's legitimate busmess interests agamst the einployee's interests in job security and protection from arbitrary or bad faith discharges. ${ }^{78}$ Before applying these exceptions to the at will rule, however, courts will need to consider any statutory protections available to the employee, and the extent to which their availability miglit preclude a common law cause of action for wrongful discharge. The availability of einployee protections under the NLRA, for instance, raises special issues regarding the preemption of einerging common law relief. The next part discusses the evolving labor law preemption doctrine and sets forth the Supreme Court's current analysis for determining when state actions are preempted by the NLRA.

II

\section{Federal Labor Law Preemption}

When it enacted the National Labor Relations Act, ${ }^{79}$ Congress was silent as to the inatter of preemption. The Supreme Court has simce developed a body of law concerning the preemptive effect of the federal labor statute. Although the Court's early decisions vacillated as to the scope of preemption, ${ }^{80}$ later decisions focus on different aspects of preemption. Two different, albeit not discrete, lines of preemption analysis have evolved: one based on a primary jurisdiction rationale and the otlier based on the Suprennacy Clause.

\section{A. Development of the Primary Jurisdiction Rationale}

Unlike preemption cases in other contexts that focus on the degree of state and federal conflict and the potential frustration of the federal scheme, federal labor law preemption cases are largely concerned with

78. See generally Comment, Protecting At Will Employees, supra note 11, at 1840-42 (good faith standard offers flexibility to address length of service, past job performance, level of employment, and economic needs of the employer); Comment, supra note 13, at 92-94 (applying a good faith standard, courts might consider a variety of factors in balancing the benefit accruing to the employer as a result of the discharge against the imjury suffered by the employee froin an arbitrary discharge).

79. 29 U.S.C. $\$ \$ 151-169$ (1976).

80. Compare Garner v. Teamsters Local Umion No. 776, 346 U.S. 485 (1953), with International Ass'n of Machinists v. Gonzales, 356 U.S. 617 (1958). 
the effect of the state's adjudication on the jurisdiction of the National Labor Relations Board (NLRB) ${ }^{81}$ In developing a comprehensive national labor law, Congress behieved common law courts and state legislatures, acting alone, were incapable of "provid[ing] an informed and coherent basis for stabilizing labor relations conflict[s]" and for striking a workable and equitable balance of power between labor and inanagement. ${ }^{82}$ Accordingly, it not only set down a federal labor pohicy but "deliberately place[d] the responsibility for applying and developing this coinprehensive legal system in the hands of an expert administrative body," the NLRB. ${ }^{83}$ The Supreme Court has therefore held that the NLRB has exclusive jurisdiction over cases falling under the NLRA, since the "duty of primary decision lies with the Board" and not with the courts. ${ }^{84}$

The Supreme Court articulated this "primary jurisdiction" rationale for NLRA preemption in an early case, Garner v. Teamsters Local Union No. 776.85 The issue in Garner was whether a Pennsylvania state court could, pursuant to a state statute, enjoin coercive recognitional picketing - that is, "whether the State, through its courts, inay adjudge the same controversy [as the NLRB] and extend its own form of relief." 86 The Court, in deciding that the state court could not, emphasized that "centralized administration of specially designed procedures was necessary to obtain uniform application of [Congress'] substantive rules and to avoid these diversities and conflicts likely to result from a variety of local procedures and attitudes toward labor controversies." 87

The Court rejected the argunient that the NLRB enforces only a public right on behalf of the public interest, while state courts protect private rights, indicating that a conflict is imminent whenever two separate renedies are brought to bear on the same activity. ${ }^{88}$ Moreover, the Court stated that the NLRA's regulation of certain types of picketing implies that other types of picketing are to be regulated by the econonics of the marketplace and therefore nuust be free front legal restraint. ${ }^{89}$

81. See Bryson, A Matter of Wooden Logic: Labor Law Preemption and Individual Rights, 51 TEx. L. Rev. 1037, 1038 n.7 (1973). See also Farmer v. United Bhd. of Carpenters, Local 25, 430 U.S. 290, 295 n.5 (1977) (care must be taken to distinguish preemption based on federal protection of the conduct in qnestion from that based on the NLRB's primary jurisdiction, although these cannot be easily separated).

82. Amalgamated Ass'n of St. Employees v. Lockridge, 403 U.S. 274, 286 (1971).

83. Id. at 288.

84. Garner v. Teamsters Local Union No. 776,346 U.S. at 489.

85. Id.

86. $I d$.

87. Id. at 490.

88. Id. at 498-99.

89. Id. at 499-500. 
Thus, Garner established the rule that a state can neither enact laws, at least with regard to strikes or picketing, prohibiting what the federal statute already prohibits, nor provide remedies for violation of such state, or the federal, law. ${ }^{90}$ Later cases indicate that the Garner rule apphes to state common law as well as to state statutory restrictions. ${ }^{91}$

\section{B. The Garmon Rule}

Subsequent to Garner, the Court firmly established the primary jurisdiction rationale as a basis for preemption in San Diego Building Trades Council v. Garmon. ${ }^{92}$ That case involved a state court action in which an employer was awarded reinedies under the state law for a umon's organizational picketing directed at the employer's custoiners and suppliers. The Supreme Court held that the state court's jurisdiction was preempted, declaring that "[w] hen an activity is arguably subject to $\S 7^{[93]}$ or $\S 8^{[94]}$ of the Act, the States as well as the federal courts inust defer to the exclusive coinpetence of the National Labor Relations Board if the danger of state interference with national pohey is to be averted."95 The Court also described two exceptions to preemption of state action: (1) where the activity regulated was "merely [a] peripheral concern" of the national labor laws, and (2) "where the regulated conduct touched interests so deeply rooted in local feeling and responsibility that, in the absence of compelling congressional direction, [the Court] could not infer that Congress had deprived the States of the power to act." 96

A inajority of the Court apphed the Garmon rule in Amalgamated Association of Street, Electric Railway \& Motor Coach Employees v. Lockridge. ${ }^{97}$ There, Lockridge was discharged at the union's request when he failed to pay his union dues. Lockridge argued that he had paid the dues in a timely inanner under the union constitution, and that his discharge therefore violated sections $8(a)(3), 8(b)(1)(A)$ and $8(b)(2)$ of the NLRA. He filed suit in state court alleging willful breach of the union's constitution and was restored to union menibership and awarded lost wages. The Idaho Supreine Court concluded that the state court had jurisdiction for two reasons. First, the action involved a

90. Id. at $489-91$.

91. See, e.g., Building Trades Council v. Kinard Constr. Co., 346 U.S. 933 (1954), rev'd per curiam, 258 Ala. 500, 64 So. $2 \mathrm{~d} 400$ (1953).

92. 359 U.S. 236 (1959).

93. 29 U.S.C. \& 157 (1976), quoted at infra note 121.

94. 29 U.S.C. $\& 158$ (1976). Section 8 sets forth those employer and union actions which constitute unfair labor practices. For the purposes of this Comment, $\$ 8$ is relevant in that an employer violates $\S 8(\mathrm{a})(1)$ by discharging an employee for engaging in activity protected by $\S 7$.

95. 359 U.S. at 245.

96. Id. at $243-44$.

97. 403 U.S. 274 (1971). 
breach of contract between a union and one of its members, enablimg the court to invoke the general common law of contracts. Second, the facts rehed on in the state court differed froin those relevant to proceedings under the NLRA. ${ }^{98}$ Applying the Garmon rule, the United States Supreme Court reversed, and held that the state action was preeinpted. ${ }^{99}$

The Court inodified the Garmon preeinption analysis in Sears Roebuck \& Co. v. San Diego County District Council of Carpenters. ${ }^{100}$ In Sears, the Court held that a state court injunction against the trespass of union pickets on Sears' property was not preempted. Here, the picketing itself was both "arguably prohibited" and "arguably protected" by the NLRA. Nevertheless, the Court found that preemption was not justified, as the controversy presented to the state court involved trespass, whereas the issue before the Board would be the legality of the picketing. ${ }^{101}$ Moreover, the Board had not had the opportunity to decide the issue, since the union had not filed an unfair labor practice charge and Sears could not file such a charge against itself. ${ }^{102}$ The Court, however, stressing that preemption might still be appropriate in cases where protected status could not be adjudicated, did address the strength of the arguably protected argument. Preemption was not appropriate in these cases because the NLRB rarely holds instances of trespass to be protected. ${ }^{103}$

Although Sears narrowed somewhat the scope of preemption under Garmon and Lockridge, the critical inquiry remains the same: whether the conduct sought to be regulated by the state was arguably protected or arguably prohibited by the NLRA.

\section{The Morton-Machinists Line}

The second line of preemption cases focuses on conduct which is neither arguably protected nor arguably prohibited under the NLRA. The critical inquiry here is whether the exercise of state authority over self-help weapons would frustrate the employer-employee balance of

98. Id. at 285 .

99. Id. at 291-93. Lockridge has been the subject of much criticism. See, e.g., Cox, Labor Law Preemption Revisited, 85 HARV. L. REV. 1337 (1972). Cox posits that state action requires preemption only where it is based on the accommodation of the interests of employers, unions, employees, or the public in employee self-organization, collective bargaiming, or labor disputes. Id. at 1356. Under this theory, the state action in Lockridge, would not have been preempted, as it involved a dispute between the union and one of its members, rather than a controversy over union organizing and collective bargaining.

100. 436 U.S. 180 (1978).

101. Id. at $197-98$.

102. Id at 201-03.

103. Id. at 203-05. 
power struck by Congress. ${ }^{104}$ In Local 20, Teamsters $v$. Morton, ${ }^{105}$ a district court awarded damages to an employer where a union, in violation of Ohio law, peacefully persuaded a secondary employer to cease doing business with the primary einployer during a strike. The Supreme Court found it necessary to determine whether, by enacting section 303 of the Labor Management Relations Act (LMRA), ${ }^{106}$ Congress had occupied the field to the exclusion of state regulation. According to the Court, a peaceful appeal to a secondary einployer is an economic weapon to be left to the marketplace and, as such, is part of the balance Congress struck between management and labor. ${ }^{107}$ The state was preempted from proscribing the self-help weapon and altering the balance. ${ }^{108}$

The Court relied on Morton in Lodge 76, International Association of Machinists v. Wisconsin Employment Relations Commission. ${ }^{109}$ In Machinists, the Court held that a state cannot prohibit a union's refusal to work overtime. The Court distimguished the primary jurisdiction cases and focused on whether Congress intended that the conduct involved remain unregulated and left to the "free play of economic forces." "110 The Court found that the state's attempt to influence the substantive terms of collective-bargaining agreements by prohibiting the use of certain economic weapons was inconsistent with the federal scheme and was therefore preempted. ${ }^{111}$

Morton and Machinists, then, established the primciple that a state may not disturb the balance of power struck by Congress by prohibiting economic weapons where the effect of its prohibition would be to frustrate the implementation of national labor policies. This principle was later reiterated in New York Telephone Co. v. New York Department of Labor. ${ }^{112}$ However, in New York Telephone, the Court found no preemption by a New York statute enabling strikers to receive unemployment compensation. Thus, the extent to which a state might disturb the balance of power between employers and employees without frustrating national labor policies is as yet unclear.

\section{Exceptions to the Labor Preemption Doctrine}

The Supreme Court has recognized several exceptions to the pre-

104. See New York Tel. Co. v. New York State Dep't of Labor, 440 U.S. 519, 531 (1979).

105. 377 U.S. 252 (1964).

106. 29 U.S.C. \& 187 (1976).

107. 377 U.S. at 259-60.

108. Id.

109. 427 U.S. 132 (1976).

110. Id. at 140 (quoting NLRB v. Nash-Finch Co., 404 U.S. 138, 144 (1971)).

111. Id. at 148-51.

112. 440 U.S. $519,530-33$ (1979). 
emption doctrine. For example, both state and federal courts have jurisdiction under section 301 of the LRMA to enforce collectivebargaining agreements, although federal law must be applied. ${ }^{113}$ Courts retam jurisdiction, then, even where the breach of the agreement is also an unfair labor practice-i.e., it mvolves conduct that is arguably protected or arguably prohibited, and is therefore within the Board's jurisdiction. ${ }^{114}$ Additionally, both state and federal courts retain jurisdiction to hear breach of duty of fair representation cases, even though such breaches may constitute an unfair labor practice. ${ }^{115}$ Moreover, as the Garmon Court acknowledged, the preemption doctrine will not be apphed to activity that concerns interests "deeply rooted in local feeling," as where the conduct involved unahicious libel, ${ }^{116}$ mass picketing and threats of violence, ${ }^{117}$ and intentional infliction of emotional distress. ${ }^{118}$ Finally, the doctrine is not applied to conduct which is only of peripheral concern to the NLRA, such that there is hittle risk of interference with the effective administration of the federal labor laws. ${ }^{119}$

Thus, the Supreine Court has delineated a two-fold preemption analysis riddled with exceptions. The following part addresses issues courts will need to resolve in applying a federal labor law preemption analysis to state wrongful discharge actions.

\section{III}

\section{Application of Labor LaW Preemption analysis to State Wrongful Discharge Actions}

To determine whether the NLRA preempts state claims under the foregoing two-fold preemption analysis, courts first inust deterinine whether the activity precipitating the employee's discharge is arguably protected $^{120}$ and therefore, under Garmon, subject to the NLRB's primary jurisdiction. Second, even if the activity is protected, an exception might apply so as to warrant the state's adjudication. Third, where the behavior does not fall under the primary jurisdiction rationale, the Morton-Machinists theory may require preeinption. This Cominent argues that in applying Garmon and Morton-Machinists, courts are actu-

113. Local 174, Teamsters v. Lucas Flour Co., 369 U.S. 95 (1962); Charles Dowd Box Co. v. Courtney, 368 U.S. 502 (1962).

114. Smith v. Evening News Ass'n, 371 U.S. 195 (1962).

115. Vaca v. Sipes, 386 U.S. 171 (1967).

116. Linn v. United Plant Guard Workers, Local 114, 383 U.S. 53 (1966).

117. UAW v. Russell, 356 U.S. 634 (1958).

118. Farmer v. United Bhd. of Carpenters, Local 25, 430 U.S. 290 (1977).

119. Linn v. United Plant Guard Workers, Local 114, 383 U.S. at 61.

120. Conversely, the courts might determine whether the employer's discharge is arguably prohibited under \&8(a)(1). See supra note 94. 
ally considering different facets of the same process: an assessment of the relative strengths of the state and federal imterests. Thus, the preemption determination ultimately turns on a balancing of the state's interest in adjudicating the controversy against the degree to which the state's action would interfere with the federal scheme.

Depending on the nature of the state claim, however, different facets of the balancing process will be triggered. State wrongful discharge actions, although grounded in a variety of legal theories, are directed at limitimg two kinds of discharges: arbitrary discharges and discharges made for improper cause. A court's preemption inquiry, or balancing process, will reflect the kind of discharge plaintiff alleges. Like the NLRA, the public policy exception to the at will doctrine prohibits an employer from discharging an employee for certain improper causes. The critical imquiry in such cases is whether the state's adjudication encroaches on the primary jurisdiction of the NLRB under the Garmon rule and, if so, whether the state interest alleged is sufficient to override the potential frustration of the federal scheme. Wrongful discharge actions based on implied-im-fact or implied-in-law contracts, on the other hand, are largely directed toward limiting arbitrary discharges. The NLRA itself does not protect employees from arbitrary discharge. Thus, unless an "improper cause" discharge is also alleged, the protected status of the employee's conduct is not at issue, and courts need not invoke the Garmon analysis. Potential frustration of the federal scheme turns on whether a state remedy would upset the balance of power between the employer and employee. This will occur only in cases where employees are covered by a collective-bargaining agreement.

The following Section applies the foregoing preemption analysis to those cases in which an improper cause for the discharge is allegedi.e., primarily pubhic policy cases. The next Section will address the preemption issues arismg in state wrongful discharge actions based on contract.

\section{A. Public Policy Cases}

\section{Arguably Protected Conduct}

Under the Garmon rule, a state wrongful discharge action will be preempted if the employee's conduct givmg rise to the termination is arguably protected by the NLRA and an exception does not apply. To warrant section 7 protection, an employee's activity must be both: (1) conducted for the purpose of collective bargaining or other mutual aid or protection; and (2) concerted. ${ }^{121}$ While courts may not encounter

121. 29 U.S.C. $\S 157$ (1976). Section 7 provides that: 
difficulties determining whether conduct meets the first requirement, the scope of "concerted" is far from settled. The lack of clarity arguably expands the ambit of "arguably protected" conduct and thus the potential for preemption.

\section{a. Mutual Aid or Protection}

The Supreme Court recently imdicated that section 7's "mutual aid or protection" clause is to be generously construed. In Eastex, Inc. $v$. $N L R B,{ }^{122}$ the Court implied that activity conducted for mutual aid or protection encompasses employee activity conducted "to improve terms and conditions of employment or otherwise improve their lot as employees," even when such activity is directed to charmels outside the immediate employer-employee relationship. ${ }^{123}$ The Court upheld the Board's determination that the distribution of a union newsletter was protected, even though the newsletter's purpose was to encourage national prolabor political activity. ${ }^{124}$ The Court reasoned that by its use of the broader language "mutual aid or protection," along with the narrower "self-organization" and "collective bargaining," Congress in section 7 had acknowledged that labor's cause "often is advanced on fronts other than collective bargaining and grievance settlement within the innediate eniploynient context."125 Many state wrongful discharge cases may thus fall within the mutual aid or protection rubric.

\section{b. Concerted Activity}

In addition to the requirement that it be for mutual aid or protection, activity will be protected by section 7 only if it is "concerted." Section 7 does not protect "personal gripes" by individual employees. ${ }^{126}$ The law as to when employee activity is "concerted" is presently im a state of flux. A major area of contention surrounds the question of whether individual activity conducted for mutual aid or protection is protected.

Employees shall have the right to self-organization, to form, join, or assist labor organizations, to bargain collectively through representatives of their own choosing, and to engage in other concerted activities for the purpose of collective bargaining or other mutual aid or protection, and shall also have the right to refrain from any or all of such activities....

122. 437 U.S. 556 (1978).

123. Id at 565 .

124. Id at 569 .

125. Id at 565 .

126. See, e.g., Tabernacle Community Hosp. \& Health Center, 233 N.L.R.B. 1425 (1977) (no unfair labor practice found where employee was discharged for writing a letter complaining of unfair treatment when she tried to transfer to another department-her coinplaimt was "purely personal"); Del E. Webb Realty \& Manageinent Co., 216 N.L.R.B. 593 (1975) (no unfair labor practice found where employee wrote letter protesting employer's requirenent that employees work an additional half hour without increase in pay). 
At present, the Board and the circuit courts follow different theories. A "constructive concerted activity" theory has prevailed in several NLRB decisions. The Board is willing to find concerted activity when an individual employee protests an employinent condition that constitutes a matter of concern to other employees, ${ }^{127}$ especially where the employee is covered by a collective-bargaining agreement, ${ }^{128}$ or where the employee's complaimts are based on health and safety legislation. ${ }^{129}$ In Alleluia Cushion Co. ${ }^{130}$ for instance, a nonunion einployee was discharged when he complamed to the California Occupational Safety and Health Administration about his employer's safety regulation violations. Finding that the discharge constituted an unfair labor practice, the Board stated that "where an employee speaks up and seeks to enforce statutory provisions relating to occupational safety designed for the benefit of all einployees . . . we will find an implied consent thereto and deem such activity to be concerted." ${ }^{131}$ The Board, however, has not consistently deemed concerted individual employee's activities that are of mutual concern to other employees. ${ }^{132}$

Most circuit courts hold that individual activity is not protected. ${ }^{133}$ The Nimth Circuit, declining to follow the Board's reasoning in Alleluia Cushion, has found that an individual's filing of a safety coinplaint does not constitute protected concerted activity. ${ }^{134}$ In contrast, the Sec-

127. See, e.g., St. Joseph's High School, 236 N.L.R.B. 1623 (1978) (unfair labor practice found where employer refused to renew teaching contract after teacher distributed report regarding labor relations problems prior to visit by accreditation team), vacated on other grounds, 248 N.L.R.B. 901 (1980).

128. See B \& M Excavating, Inc., 155 N.L.R.B. 1152 (1965), enforced, 368 F.2d 624 (9th Cir. 1966).

129. See Pink Moody, Inc., 237 N.L.R.B. 39 (1978).

130. 221 N.L.R.B. 999 (1975).

131. Id. at 1000 .

132. See Gorman \& Finkin, The Individual and the Requirement of "Concert" under the National Labor Relations Act, 130 U. PA. L. REV. 286, 297-99 (1981); cases cited id. Gorman and Finkin's construction of protected activity would extend $\S 7$ protection even further than that under the Board's constructive concerted activity theory. They contend that the history and policies underlying the enactınent of $\S 7$ support an exteusive reading of $\S 7$, encompassing an individual employee's "right to complain and to act in his own self-interest." They point out the anomalies which result from allowing an individual to be discharged for protesting conditions in an individual capacity when the protests would have been protected if the individual had been accompanied by another employee. Id. at 344. Their proposal, lowever, may burden the Board's already heavy caseload, and as they acknowledge, may make the Board "an available forum for challenging discipline of the 'uncooperative' employee" coinplaining of working conditions. Therefore, they suggest deferring the unfair labor practice hearing until available grievance and arbitration procedures have been exhausted. $I d$. at 357 . These concerns arguably support the availability of the state courts as a forum for individual grievances falling within the scope of the public policy exception where the employee is not covered by a collective-bargaining agreeinent.

133. See id. at 310-28; cases cited id.

134. See NLRB v. Bighorn Beverage, 614 F.2d 1238 (9th Cir. 1980), where the Ninth Circuit found no concerted activity where an employee reported carbon monoxide poisoning from truck fumes to the Department of Health. The court stated that "the implied concerted action theory is 
ond Circuit found protected concerted activity in $N L R B v$. Interboro Contractors, Inc., where an individual einployee complained to his einployer and his union about work related matters. ${ }^{135}$ Even that circuit, however, has since declined to extend section 7 protection to cases where the enployee is not covered by a collective bargaining agreeinent and the individual activity is not "looking toward group action." 136

The scope of section 7 protection thus depends on which of the foregoing theories ultimately prevails. Under the circuit courts' current construction of concerted activity, the state courts provide an excellent forum for einployees to seek redress for discharges made in retaliation against individual protests concerning working conditions where such discharges anrount to a contravention of public policy. Given the Board's willingness to construe concerted activity inore broadly, however, the anibit of arguably protected conduct expands, and thus, the potential for preemption of state wrongful discharge actions is greater. Whether the state action involves an exception to preemption, then, will often be critical to the preemption determination. ${ }^{137}$

a legal fiction presenting an unwarranted expansion of the definition of concerted action unsupported by a statutory basis." Id. at 1242. See also NLRB v. C \& I Air Conditioning, 486 F.2d 977 (9th Cir. 1973) (reversing the Board's finding of protected concerted activity where the employee had complained of a hazardous stairway). Similarly, the Sixth Circuit declined to rely on the Alleluia Cushion doctrine but found that an employer's complaints about excessivc paint fumes were protected concerted activity because "two employees essentially [agreed] to take up a common grievance with the proper authorities." Jim Causley Pontiac v. NLRB, 620 F.2d 122, 124 (6th Cir. 1980). See also Krispy Kreme Doughnut Corp. v. NLRB, 635 F.2d 304, 308 (4th Cir. 1980) (distinguishing between "individual action "intended to enlist the support and assistance of other einployees' and action 'for the benefit of other employees only in a theoretical sense,' " and declining to enforce the Board's finding that filing a workmen's compensation claim is a protected concerted activity).

135. 388 F.2d 495, 500 (2d Cir. 1967) ("While interest on the part of fellow einployees would indicate a concerted purpose, activities imvolving atteinpts to enforce the provisions of a collective bargaining agreement nay be deemed to be for concerted purposes even in the absence of such interest by fellow employees."). Although the Fourth and Seventh Circuits have followed the Interboro doctrine, several circuits, including the Third, Fifth, and Sixth, have expressly rejected it. See Ontario Knife Co. v. NLRB, 637 F.2d 840, 845 (2d Cir. 1980); cases cited $i d$.

136. See Ontario Knife Co. v. NLRB, 637 F.2d 840, 845 (2d Cir. 1980) (Except in situations where an employee was asserting rights under a collective-bargaining agreenent, "[n]ot only must the ultimate objective be 'inutual' but the activity must be 'concerted' or . . . must be looking toward group action."). Similarly, the Eighth Circuit reversed the Board's finding of concerted protected activity where a female employee refused to work on an assignment on which unale employees were paid more than females for performing the same work. Because she acted alone in refusing to work and she was not covered by a collective-bargaining agreement, the court found that her activity was not protected. NLRB v. Dawson Cabiet Co., 566 F.2d 1079 (8th Cir. 1977).

137. Even where they are concerted and conducted for mutual aid or protection, certain enployee activities have been held to be "unprotected." These activities-such as sit-down strikes, "quickie" work stoppages and slowdowns, wildcat strikes and disloyalty-are neither protected by $\$ 7$ nor prohibited by \& 8. See generally R. GoRMan, Basic TeXT ON LABOR LaW 303-25 (1976). In these cases, whether states inay regulate such unprotected activity requires an application of the Morton-Machinists preemption analysis. Preenption will occur when the state's prohibition of the 


\section{Exceptions to the Preemption Doctrine}

As mentioned earlier, ${ }^{138}$ even when conduct is arguably protected under the NLRA, states may still regulate the conduct falling within a recognized exception to preemption. First, states are permitted to adjudicate claims involving strong local concerns. For example, state jurisdiction is allowed im cases imvolving violence or threats to the public peace ${ }^{139}$ because, according to Garmon, "tlle compelling state interest, in the scheme of our federalism, im the mamtenance of domestic peace is not overridden in the absence of clearly expressed congressional direction." 140 Second, states may adjudicate claims where the controversy lies on the periphery of national labor policies. An example of this arose when a union member sued the union for breach of contract and for physical and mental suffering after he was expelled from union membership in violation of the union constitution and by-laws. ${ }^{141}$ In two later cases, the Supreme Court elaborated on these exceptions. In Linn v. United Plant Guard Workers, Local $114,{ }^{142}$ the Court held that where false and defaniatory statements are circulated during a union organizing campaign, a court may apply state remedies if the plaintiff pleads and proves that the statement was circulated with malice. And, in Farmer v. United Brotherhood of Carpenters, Local 25, ${ }^{143}$ the Court found that a umion niember might recover damages from the union and its officers for intentional infliction of emotional distress even though the plaimtiff's allegations might have warranted filing unfair labor practice charges. However, the Court limited the exception, holding that the state tort must "be either unrelated to employment discrimination or a function of the particularly abusive manner in which the discrimination is accomplished or threatened rather tlian a function of the actual or threatened discrimination itself." 144

The Court in Linn and Farmer delineated several factors courts should consider in determining whether the state's adjudicaton is preempted: whether the activity is protected, the strength of the state interest mvolved, whether the activity involves a central or mere peripheral concern of the Act, the overlap of issues to be determined by the court with those to be considered by the Board, and whether the

discharge would frustrate the federal labor scheme. See infra notes 162-72 and accompanying text.

138. See supra text accompanying notes 116-19.

139. E.g., UAW v. Russell, 356 U.S. 634 (1958); Youngdahl v. Rainfair Inc., 355 U.S. 131

(1957); United Constr. Workers v. Laburnum Constr. Corp., 347 U.S. 656 (1954).

140. 359 U.S. at 247.

141. International Ass'n of Machinists v. Gonzales, 356 U.S. 617 (1958).

142. 383 U.S. 53 (1966).

143. 430 U.S. 290 (1977).

144. Id. at 305. 
Board has authority to award relief for the harm allegedly suffered. ${ }^{145}$ The weiglit to be placed on each factor, however, is as yet unclear. ${ }^{146}$ State and lower federal courts grappling with the Garmon rule and its exceptions have empliasized and applied different factors delineated in Linn and Farmer, and their reasoning has yielded imconsistent decisions. ${ }^{147}$ These courts have adhered to the Supreme Court's admonition that "[i]t is not the label affixed to the cause of action under state law that controls the determination of the relationship between state

145. Farmer, 430 U.S. at 302-05; Linn, 383 U.S. at 61-62.

146. Several of the Court's early decisious, for instance, placed considerable weight on the fact that the Board was not entitled to grant full relief. See, e.g., UAW v. Russell, 356 U.S. 634 (1958) (employee's state damage recovery for injuries caused by union's tortious conduct not preempted); International Ass'n of Machinists v. Gonzales, 356 U.S. 617 (1958) (possibihity of partial relief from the Board would not bar plaintiff from seeking all available state remedies). In Garmon, lowever, the Court cautioned that the "type of conduct" involved, not "the fact that the state remedy lad no federal counterpart," is determinative of the preemption decision. 359 U.S. at 247-48. Still, the Linn Court's later reliance, in part, on the lack of available remedy through the Act indicates that courts might still consider this as one factor in making the preemption determination.

Professor Cox has suggested that state adjudication should not be preenpted where it involves "state laws of general apphication," as opposed to labor regulations. Cox, Recent Develop. ments in Federal Labor Law Preemption, 41 OHIO ST. L.J. 277, 293 (1980). This view has been criticized in light of both the difficulties inherent in distinguishing laws of general applicability from labor regulation and the potential danger that such a rule would upset the balance between labor and management and the uniform application of national labor policies. See generally Meltzer, The Supreme Court, Congress, and State Jurisdiction Over Labor Relations: 1, 59 Colum. L. Rev. 6, 47-55 (1959). The Court flatly rejected Cox's view, first in Garmon, 359 U.S. at 244, and agam in Farmer, 430 U.S. at 300 . Several Justices, however, have indicated that the "general applicability" of a state law may not be completely irrelevant to the preeinption determmation. The majority in Sears, for example, noted that "the Court las allowed a State to enforce certain laws of general applicability even though aspects of the challeuged conduct were arguably prohibited by $\$ 8$ of the NLRA." 436 U.S. 180, 194-95 (1978). Similarly, the plurality in New York Telephone indicated that the Court's "cases have consistently recognized that a congressional intent to deprive the States of their power to enforce such general laws is more difficult to infer than an intent to preempt laws directed specifically at concerted activity." 440 U.S. at 533.

147. Courts have not had difficulty applying the exceptions in defamation suits imvolving malice. See, e.g., Hasbrouck v. Sheet Metal Workers Local 232, 586 F.2d 691 (9th Cir. 1978); Hotel \& Restaurant Employees Union, Local 681 v. Anaheim Operating, Inc., 82 Cal. App. 3d 737, 147 Cal. Rptr. 510 (1978), cert. denied, 440 U.S. 914 (1979); Henderson v. Teamsters Union Local 313, 90 Wash. 2d 666, 585 P.2d 147 (1978). But see Hasten v. Phillips Petroleum Co., 640 F.2d 274 (10th Cir. 1981) (malicious libel action for statements made in discharge letter preempted because statements were discussed in grievance proceedings and therefore privileged).

Other state claims, however, have posed problems. Compare, e.g., Hale v. Belknap, Inc., 110 L.R.R.M. 2397 (Ky. Ct. App. 1981) (no preemption of state fraud and misrepresentation clains where nonunion ineinbers alleged they were induced to accept employment characterized as permanent during a strike but were later replaced by striking einployees, because the action was a peripheral concern to the NLRA and involved substantial local feeling and responsibihity), with Gibson v. UAW, 102 L.R.R.M. 2922 (Micl. Cir. Ct. 1979) (Garmon doctrine required preemption of employees' suit against the union for tortious misrepresentation, fraud, and interference with a contract during an organizational drive because both the NLRB's and the court's inquiries would involve the misleading nature of the representations). 
and federal jurisdiction." 148 Ultimately, courts will need "to determine the scope of the general rule by examining the state interests in regulating the conduct in question and the potential for interference with the federal regulatory scheme." 149 Courts will thus need to balance the state and federal interests, first by ascertaining the potential for interference with the federal scheme, and next, by determining whether there is an overriding state interest. Factors suggested by the Court in Linn and Farmer might best be incorporated into the latter determination, as discussed below.

\section{Frustration of the Federal Scheme}

Determining potential interference with the federal scheme requires a consideration of the purposes and policies Congress sought to advance when it enacted the NLRA. Section 1 of the NLRA states that the policy underlying the Act is to protect employees' rights to organize and bargam collectively, and thus to encourage "tlie friendly adjustment of industrial disputes," and to restore "equality of bargaining power between employers and employees."150 In enactimg the NLRA, Congress prohibited certain forms of economic pressure, thereby strikmg a "balance ... between the uncontrolled power of management and labor to further their respective interests."151 Other forms of economic pressure were imtended to be "unregulated because [they were] left 'to be controlled by the free play of economic forces." "152

Frustration of the federal scheme will occur when a state's adjudication would be detrimental to these federal purposes and policies. Thus, where an einployee is engaged in union activity or two or inore employees protest their wages, a state claim would be preempted. ${ }^{153}$ Similarly, wliere employees engage in certain "unprotected" beliavior, ${ }^{154}$ sucli as wildcat strikes, violence, or disloyalty, a state's attempt to curtail their discliarges-the economic weapon of the employer-

148. Local 100, United Ass'n of Journeymen v. Borden, 373 U.S. 690, 698 (1963). See, e.g., Iowa Beef Processors v. Gorman, 476 F. Supp. 1382 (N.D. Iowa 1979); Silkwood v. Kerr-McGee Corp., 637 F.2d 743, cert. denied, 454 U.S. 833 (1981).

149. Farmer, 430 U.S. at 297.

150. 29 U.S.C. $\$ 151$ (1976).

151. Local 20, Teamsters Union v. Morton, 377 U.S. 252, 259 (1964) (quoting Carpenters Local 1976 v. NLRB, 357 U.S. 93, 100 (1958)).

152. Lodge 76, Int'l Ass'n of Machinists v. Wisconsin Enployment Relations Comm'n, 427 U.S. 132, 140 (1976) (quoting NLRB v. Nash-Fimch Co., 404 U.S. 138, 144 (1971).

153. Courts have so found. See, e.g., Viestenz v. Fleming Co., Inc., 681 F.2d 699 (10th Cir.) (claim alleging public pohicy violation where plaintiff was allegedly discharged because of union activity constitutes an unfair labor practice allegation and is, therefore, preempted), cert. denied, 103 S. Ct. 303 (1982); Danculovich v. Peter Eckrich \& Sons, 110 L.R.R.M. 2110 (W.D. Micl. 1982) (state contraet claim that plaintiffs were discharged without cause preempted where discharges related to collective bargaining or concerted union activity).

154. See supra note 137. 
would upset the balance struck by Congress. Conversely, a state may address matters falling entirely outside the scope of the regulatory scheme, that is, matters unrelated to collective bargaining, self-organization, or mutual aid or protection, even in some cases where its adjudication could upset the balance of power between employer and employee. For example, a state's adjudication of wrongful discharge claims where an employee refused to engage in illegal conduct (e.g., fixing of gasoline prices or committing perjury) falls outside the scope of the NLRA, even though the adjudication could result in loss of an employer's power.

The potential for frustration of the federal scheme, however, imcreases as state adjudication touches on matters which might also be addressed by the Board. In such cases, courts should consider the following factors in determining the degree of frustration: (1) whether the nature of the employee's activity is a central concern of the NLRA; (2) the similarity of the issues to be addressed by the court and the Board; (3) the Board's expertise in deciding the particular issues involved; and (4) whether the Board could provide redress for the injury claimed. As the Supreine Court's opinions have illustrated, none of these factors will be dispositive. Moreover, even where the issues to be addressed by the Board and court overlap, and the remedies available are similar, a strong state interest may be sufficient to override the potential frustration of the federal scheme.

As part of its determination whether a state interest will be sufficient to override the potential frustration of the federal scheme, a court might look to the larger realm of preemption cases, including those falling outside the labor context. One commentator has reviewed a number of federal preemption cases and has found that the state interest is stronger: (1) when it is directed at "territorial" as opposed to "extraterritorial" protection; (2) when it protects persons from fraud or physical imjury, rather than when it alters the parties' econounic interests; or (3) when it involves public safety and order and protection of citizens' basic rights to shelter and livelihood. ${ }^{155}$ Courts might use such cases as guideposts in decidimg whether a particular state interest justifies more than a trivial interference with the federal regulatory scheme.

\section{Balancing State and Federal Interests in Public Policy Cases}

Allowing states to prohibit discharges in cases where a public policy has been violated may not, in hight of the foregoing factors determining the degree of frustration of the federal scheme, create an

155. See Note, A Framework for Preemption Analysis, 88 YALE L.J. 363, 378-82 nn.89-90 \& 115 (1978). 
obstacle to the full effectiveness of the scheme. First, state adjudication of public policy matters is not imconsistent with the NLRA's purposes and policies to protect employees im their efforts to organize and bargam collectively. ${ }^{156}$ However, courts still need to examine the nature of the activity involved. Where an employee alleges that she was discharged for activity central to the concerns of the Act, such as union activity, the state adjudication risks interference with the federal regulatory scheme. Where employees, acting in concert, protest some condition of employment, courts need to determine whether that condition involves a strong state interest or one which relates primarily to the economic positions of the parties. Where conditions such as wages, hours, promotions or job assignments are involved, state adjudication would interfere with the economic balance of power established by Congress. On the other hand, where an individual employee acts alone in protesting an employnient condition which violates public pohcy, a lesser state imterest should warrant state adjudication, at least until such time as the Board and courts consistently find the activity to be protected. 157 Finally, where the employee's activity involves "unprotected" conduct, ${ }^{158}$ the state's adjudication risks interference with the area intended to be left to the free play of economic forces.

A second reason why state adjudication of public policy claims might not interfere with the federal scheme relates to the focus of the adjudication. In inost public policy cases, even if the discharge occurs within the context of employees' organizing efforts, the court's niquiry will focus on the issues related to the alleged public policy violation, not the potential unfair labor practice (assuming the organizing itself is not asserted as the activity violatimg public policy). The Court in Linn and Farmer imdicated that courts should refranı fronı deciding issues which could come before the Board. This, however, may not always be possible. As in the Court's violence cases, state actions involving a strong state interest may require consideration of the activity in the full context im which it occurred. Thus, where two employees report a

156. Although the NLRA occupies the field with respect to collective bargaining and selforganization, it does not occupy the field of employee protection. By adjudicating public policy claims, states might supplement protections offered by the NLRA. That both the Board and state courts have jurisdiction to award back pay does not create a conflict of remedies. Russell, 356 U.S. 634. Nor do parallel purposes-here, employment protection-alone warrant preemption. See Colorado Anti-Discrimination Comm'n v. Continental Air Lines, Inc., 372 U.S. 714 (1963) (Colorado state statute prohibiting discrimination not invalid although several federal statutes already protected persons in interstate cominerce from racial discrimination).

157. Prolonged inconsistency as to the scope of "concerted" and "protected" activity and potential preemption determination based on an expanded "arguably protected" concept, see supra notes 126-37 and accompanying text, could lave the effect of preventing states from vindicating their public policies and precluding plaintifis from pursuing meritorious state policy claims.

158. See supra note 137. 
safety hazard to the state agency, both the court and the Board will need to consider whether the discharge occurred for this or some other reason. This is true although the court's decision will turn on whether the employer's discharge violated public policy while the Board's unfair labor practice determination will rest on whether the discharge interfered with the einployees' rights under section 8(a)(1) of the NLRA.

A third reason to except preemption in public pohicy cases is that courts have greater expertise in adjudicatimg controversies involving their public policies than the Board, whose inquiry focuses on the concerted nature of the activity and whether it was conducted to improve the terms and conditions of einployment.

A fourth reason is that the regulatory scheine set up by Congress may not provide the full relief available for the public policy violations. The Board's remedy is limited to reinstateinent and back pay, while the courts are entitled to award coinpensatory and punitive damages for the tort cause of action.

Ultimately, in those cases where there is potential interference with the federal scheme-where employees are discharged for arguably protected behavior and the reinedies available and issues to be considered in both foruins overlap - the preemption question will turn on the strength of the state interest involved. Here, courts will need to distmguish claims involving health, safety, public order, discrimination, and livelihood (e.g., minimum wage) froin those in which the primary effect of the adjudication would alter the economic positions of the parties. Only claims falling within the former category involve an overriding state interest sucls that the state adjudication should be allowed.

A different result may obtain where the einployee asserting a public policy violation is covered by a collective-bargaining agreeinent containing a provision requiring just cause for terinination. In such cases, the potential for interference with the federal scheine increases. First, enforcing the teruns of a collective-bargainimg agreenent is an integral aspect of the scheine. Second, the arbitrator's determmation will focus on whether the termination was justified, while the court will consider whether the termination violated public policy. Because discharges in violation of public policy are generally "unjust" discharges, the issues to be considered relating to the reasons for the discharge will be similar, if not identical, in both forums. Third, in decidmg whether the collective-bargaining agreeinent was breached and the employee wrongfully terminated, the arbitrator has a great deal of expertise regarding the norns and practices of the industry. On the other hand, courts may be better equipped to litigate cases involving strong public policies. Also, the availability of more extensive relief through the 
courts militates agamst the potential frustration of the federal scheme revealed from the foregoing considerations.

Although the potential for frustration of the federal scheme increases when employees are covered by a collective-bargaining agreement, it is argued here that a strong state interest should warrant the availability of both forums. This view is supported by the Supreme Court's reasoning in Alexander v. Gardner-Denver Co. ${ }^{159}$ There, a black employee filed a grievance under a collective-bargaining agreement alleging that he had been discharged without just cause. He then brought a title VII suit against his einployer. The Supreme Court reversed the lower court's finding that the employee was bound by the grievance arbitration decision and was therefore precluded from sumg under title VII. The Court indicated that no inconsistency results from allowing imdependent statutory and contractual rights to be enforced in their respective forums. ${ }^{160}$

The Court's reasoning emphasized the independent origims of the employee's contractual and statutory rights, Congress' intent that federal courts have final responsibility for enforcing title VII, and the mappropriateness of arbitration as a forum for vindicating title VII rights. There are two reasons why arbitration is mappropriate. First, the arbitrator's role is to effectuate the parties' intent in light of the "law of the shop, not the law of the land." Second, judicial factfinding is more formal and comprehensive than arbitration factfinding, and is thus more suitable for resolving title VII issues. ${ }^{161}$

Although Alexander is readily distinguishable from state wrongful discharge actions, as it mvolved a federal statute in which Congress set up a comprehensive regulatory sclieme, the Court's reasoning might be extended to wrongful discharge cases. States should not be preempted from adjudicating claims where an employee's rights origmate outside the contractual context or where adjudication has traditionally fallen to state courts better equipped to vindicate state interests and award full relief.

Applymg the Alexander Court's reasoning will make a difference mainly in borderline cases. This is where an individual employee's protest of an employment condition does not assert a coinpelling state mterest but (1) still touches on public policy and (2) would be seen as a "personal gripe," rather than protected concerted activity by the courts of appeals. An example of such a borderline case is an employee's protest of an employer's requirement that employees submit to a polygraph test. Another might arise where an employee relies on a state

159. 415 U.S. 36 (1974).

160. Id. at $43,49-51$.

161. Id. at 57-58. 
statute requiring employers to furnish employees with uniforms and safety shoes to protest the employer's requirement that employees purchase their own uniforms and safety shoes. If the employee is not covered by a collective-bargaining agreement, state adjudication of the public policy claim should be allowed because, under the circuit courts' strict construction of the concerted activity requirement, there is little risk of interference with the federal scheme. Where the employee is covered by a collective-bargaining agreement (and, for imstance, the agreement provides that employees will furnish their own uniforms and safety shoes), states should refrain from deciding such public policy cases unless the employee asserts a compelling state imterest.

In sum, the preemption determination in public policy cases turns on a balancing of state and federal interests. Where an employee's claim asserts a vital state interest, the state action should be allowed, whether or not the employee is covered by a collective-bargaining agreement. Where the claim involves protected concerted activity or "unprotected" conduct, the state adjudication risks substantial interference with the federal scheme, and sliould be allowed only in cases in which an overriding state interest is asserted. Similarly, where there is a collective-bargaining agreement, an overridimg state interest should be required to allow the controversy to be presented in both forums. Finally, in the absence of a collective-bargaining agreement, a lesser state interest should entitle state courts to adjudicate claims involving individual protests not, in the courts' view, protected by the Act.

\section{B. Wrongful Discharge Cases Based on Contract}

\section{Implied-in-Fact Contract Cases}

Preemption of suits agamst an employer for breach of an implied contract right, in contrast with public policy cases, will turn largely on whether the employee is covered by a collective-bargaining agreement. Unlike public policy cases that protect employees from discharges for an "improper cause," wrongful discharge actions based on implied-imfact contract rights primarily address arbitrary discharges. Thus, unless an "improper cause" for the discharge is also alleged, the protected status of an employee's conduct is not at issue, and courts need not invoke the Garmon preemption analysis. Where employees are covered by a collective-bargaining agreement, lowever, they are usually protected against termination without just cause under a provision in the agreement. In such cases, the state's adjudication risks substantial interference witli the federal scheme in several ways.

First, the Supreme Court made it clear that although state and federal courts have concurrent jurisdiction under section 301 of the NLRA to enforce collective-bargaining agreements, they must apply the fed- 
eral common law of collective-bargaining agreements. ${ }^{162}$ A collectivebargaining agreement is not an ordinary contract and will "not necessarily [be] interpreted according to the general laws relating to the interpretation of contracts." 163 It must be interpreted with reference to the context in which it arose, including the peculiarities of the given industry and the particular einployment relation. ${ }^{164}$ Thus, a state court may neither impose its own contract principles on the collective-bargaining agreeinent, nor apply such principles in interpreting the contract.

Second, the Court has indicated that where employees are covered by a collective-bargaining agreement, they may not take advantage of individual contracts to limit the teruns of the agreement. ${ }^{165}$ Allowing a court to recognize an implied promise to terminate only for just cause where the terins of a collective agreement provide a remedy for unjust discharge might detract froin the teruns of the agreenent and undermine the union's exclusive right to represent the employees. ${ }^{166}$ Sliould an einployee seek redress in a state court, an unfavorable state court determination risks diminishing the rights which may have been available to her througln the collective-bargaining agreenent.

Finally, the Court indicated in Machinists that a state inay not alter the balance of power struck by Congress in attempting to influence the substantive terins of a collective-bargaining agreement. ${ }^{167} \mathrm{~A}$ termination for just cause provision is the subject of collective bargaining. Whether the collective agreement contains suclı a provision, the recognition of an implied contract right to termination for just cause grants an economic weapon to the einployee, weakening the employer's bargaining position, and altering impermissibly the balance of power be-

162. See supra note 113 and accompanying text.

163. Kellogg Co. v. NLRB, 457 F.2d 519, 524 (6th Cir.), cert. denied, 409 U.S. 850 (1972).

164. United Steelworkers v. Warrior \& Gulf Navigation Co., 363 U.S. 574, 578-79 (1960);

United Steelworkers v. American Mfg. Co., 363 U.S. 564, 570 (1960) (Brennan, J., concurring).

165. J.1. Case Co. v. NLRB, 321 U.S. 332 (1944).

166. Section 9(a) of the NLRA, 29 U.S.C. \& 159(a) (1976), states the exclusivity principle as follows:

Representatives designated or selected for the purposes of collective bargaining by the majority of the employees in a unit appropriate for such purposes, shall be the exclusive representatives of all the einployees in such unit for the purposes of collective bargaining in respect to rates of pay, wages, hours of employinent, or other conditions of employinent....

A more difficult case for preenption hes where employees are represented by a union but a collective-bargaining agreement either has not yet been reached or it has expired and new teruns and conditions have not yet been negotiated. Although the union's status is that of the einployees' exclusive representative, it is arguable that state actions should not be preempted in such cases because the terms and conditions governing the einployment relationship have not yet. been agreed upon.

167. Lodge 76, Int'l Ass'n of Machinists v. Wisconsin Einployment Relations Comm'n, 427 U.S. 132, 153 (1976). 
tween employers and employees struck by Congress. ${ }^{168}$

Granting implied contract rights to employees covered by a collective-bargaining agreement thus risks substantial interference with the federal scheine. The potential for interference is even more apparent when the identity of issues to be decided by the court and an arbitrator, the arbitrator's expertise in determining such matters, and the similarity of relief available in both forums are considered. ${ }^{169}$ The state's interest in deciding the implied contract claim is not sufficient, in itself, to override the potential interference with the federal scheme. The NLRA thus preempts state implied contract claims in cases where the aggrieved einployee is covered by a collective bargaining agreement.

If no collective-bargaining agreement is in effect, the state impliedim-fact contract claim will not be preempted so long as the employee is protesting an arbitrary discharge. Should the employee assert an "improper cause" for the discharge, however, courts will need to look at the nature of the activity which precipitated the termination to determine whether the action is preempted. If the activity is arguably protected and no overriding state interest is alleged, the state action is precluded under Garmon. ${ }^{170}$ The state interest in applying its own contract law is not sufficient in itself to warrant the state adjudication where there is potential interference with the federal Act.

168. A similar argument, however, was rejected by a plurahity of the Supreme Court in Malone v. White Motor Corp., 435 U.S. 497 (1978). There, the Eighth Circuit had found that Minnesota's Private Pension Benefit Protection Act, imposing a "pension fundimg" charge against employers who ceased to operate a place of employment or a pension plan, was preempted. The court indicated that because, under Machinists, states could not control the economic weapons of the parties used in bargaining, they could not control the substantive terms of the contract resulting from that bargaining. The Supreme Court reversed, indicating that

there is nothing in the NLRA . . . which expressly forecloses all state regulatory power with respect to those issues, such as peusion plans, that may be the subject of collective bargaining. If the Pension Act is pre-empted here, the congressional intent to do so must be implied from the relevant provisions of the labor statutes.

Id. at 504-05 (emphasis in original). The potential frustration of the federal scheme in state contract claims, however, exceeds that present in Malone. The state court's inquiry in the contract claim would be identical to that of the arbitrator-namely, whether the employee was discharged for just cause. Allowing state claims facilitates employees' efforts to circuinvent the grievance procedure where they so desire. Thus, if the state is allowed to impose essentially identical terms to those bargained for through collective bargaining, not only is the eunployer's bargaining position weakened, but the regulatory scheme calling for adjudication of such matters with reference to the federal common law of collective bargaining is also frustrated.

169. The arbitrator might award reinstatement with back pay, while the court unight grant an injunction and danages for breach of contract. The remedies are similar in that neither provides for punitive damages. See CAL CIv. CoDE \& 3294(a) (West Supp. 1982). However, the state reunedy is somewhat broader in that the aggrieved employee might secure damages foreseeable at the time the contract was inade. $C f$. Hadley v. Baxendale, 156 Eng. Rep. 145 (1854).

170. Thus, where an employee alleges that she was terminated without just cause because she was engaged in union or other protected activity, a court should find the state action preempted. See, e.g., Danculovich v. Peter Eckrich \& Sons, 110 L.R.R.M. 2110 (W.D. Mich. 1982). 


\section{Implied-in-Law Contract Cases}

The preemption of a cause of action for breach of the implied-inlaw covenant of good faith and fair dealing also depends on whether the aggrieved employee is covered by a collective-bargaining agreement. The availability of tort damages for breach of the implied covenant provides sufficient impetus for a plaimtiff either to circumvent the grievance and arbitration procedures entirely and seek redress in state court, or to attempt to seek relief in both forums. Several factors, lowever, compel the conclusion that the NLRA preempts state common law actions for breach of the implied covenant when the employee is covered by a collective-bargaining agreement.

The principles justifying preemption of implied-in-fact contract rights where a collective-bargaining agreement is in effect indicate that allowing states to imply a good faith covenant similarly would risk substantial interference with the federal scheme. A state court may not impose its own contract principles, including the covenant of good faith and fair dealing, on the collective-bargaining agreement. Moreover, allowing state courts to imply a covenant of good faitl and fair dealing would enable them impermissibly to limit or condition the terms of employment. Additionally, although the good faith inquiry might encompass subjective as well as objective factors, the issues to be considered would be similar to those an arbitrator would decide in determining whether there was good cause for the discharge. Finally, the arbitrator has considerable expertise in applying the applicable industry and employer standards to determine whether the termination was justified. The state's interest im applying its own contract law does not outweigh the federal interest in maintaining the uniformity of the federal scheme and the balance of power achieved through the collective-bargaining process.

The availability of more extensive relief in the state forum also does not warrant the state's adjudication. The justifications for awarding exemplary and punitive damages for breach of the implied covenant are not present in the collective-bargaining context. The covenant of good faith and fair dealing, origmally implied in insurance contracts, requires that "neither [contracting] party will do anything which will mjure the right of the other to receive the benefits of the agreement." 171 The special nature of the relationship between an imsurer and an insured, suggesting public policy considerations, together with the imbalance of power and adhesive nature of insurance contracts, have provided courts with sufficient justification to award punitive dam-

171. Comunale v. Traders \& Gen. Ins. Co., 50 Cal. 2d 654, 658, 328 P.2d 198, 200 (1958). 
ages. ${ }^{172}$ When it enacted the NLRA, Congress addressed the imbalance of power which existed between employers and employees and struck a delicate balance to be achieved through the collective-bargainmg process. The collective-bargaining agreement is not an adhesion contract-it sets forth the terms and conditions of employinent as negotiated by the einployer and the union. Thus, although punitive damages might lielp deter certain undesirable employer conduct, the justifications for awarding sucli damages for breach of the implied covenant are not present when a collective-bargaining agreement is in effect.

Where employees are not protected by a collective-bargaining agreement, however, the recognition of the covenant of good faith and fair dealing is consistent with the federal scheine. When it enacted the NLRA, Congress acknowledged the special relationship existing between employers and employees that gives rise to public policy considerations. Congress addressed the imbalance of power between employers and employees by protectimg employees in their efforts to organize and bargam collectively for the terms and conditions of their employment. The covenant of good faith and fair dealing affords a ineasure of protection to those einployees who are not protected by the federal scheme. The covenant is thereby consistent witl the federal purpose. In sum, unless an employee's claim falls under the scope of the NLRA, either because she is covered by a collective-bargaming agreement or because she alleges that she was discharged for activity protected under the federal Act (and she alleges no countervailing state imterest), her state clami based on the miplied-in-law covenant of good faith and fair dealing will not be preempted by the NLRA.

\section{CONCLUSION}

The exceptions to the employment at will doctrine recently articulated by California courts mitigate the harsh effects of the at will rule by enabling an employee to secure redress for her wrongful discharge. Where the aggrieved employee also has statutory remedies available to her, cominon law actions might still be used to fill the gaps in statutory scheines and to provide suppleunental relief. Several doctrines, however, might preclude the availability of such state relief. This Coinunent focused on federal preemption of state comnnon law actions by the NLRA, and concluded that in order to deterinine the preeinptive effect of the NLRA, courts need to weigh the strength of the state inter-

172. Egan v. Mutual of Omaha Ins. Co., 24 Cal. 3d 809, 820, 598 P.2d 452, 457-58, 157 Cal. Rptr. 482, 487-88 (1979). Accord Seaman's Direct Buying Serv., Inc. v. Standard Oil Co., 129 Cal. App. 3d 416, 181 Cal. Rptr. 126 (1982), hearing granted, No. 82-77 (Cal. Sup. Ct. May 27, 1982). 
est in adjudicating the claim against the degree to which the state's adjudication might interfere with the federal scheme.

In most wrongful discharge cases based on public policy, an employee's assertion of a strong state interest will warrant the state action, whetler or not she is covered by a collective-bargaining agreement. In contrast, the preemption question in wrongful discharge cases based on implied-m-fact or implied-in-law contract rights will turn largely on whether the employee is covered by a collective-bargaining agreement. In cases based on one of these contract theories, where the aggrieved employee is covered by a collective-bargaining agreement, or where sle alleges that sle was wrongfully discharged because of her "concerted" activity engaged in for the mutual protection of other employees, the state action will be preempted. In all wrongful discharge cases, however, where the state lias an overriding interest im adjudicating the claim, the state court should be allowed to provide relief to the aggrieved employee witlout the threat of preemption.

Judy Hitchcock*

* B.A. 1973, University of California, Santa Barbara; M.S.W. 1978, University of California, Berkeley; third-year student, Boalt Hall School of Law, University of California, Berkeley. 